\title{
The Effect of the Carbon Tax Value on the Optimal Parameters and Characteristics of Coal Power Plants
}

\author{
Alexander KLER ${ }^{1}$, Pavel ZHARKOV ${ }^{*}$, Yulia POTANINA ${ }^{3}$, Andrey MARINCHENKO ${ }^{4}$, \\ Nikolai EPISHKIN ${ }^{5}$ \\ 1-5 Melentiev Energy Systems Institute of Siberian Branch of the Russian Academy of Sciences \\ (ESI SB RAS), 130, Lermontov Str., Irkutsk, 664033, Russia
}

\begin{abstract}
The paper investigates the effect of the carbon tax on the optimal parameters and indicators of two coal power plants: a steam turbine power unit with coal dust burning in a steam boiler and an internal gasification combined cycle power plant. Sufficiently detailed mathematical models have been developed for the considered plants that are focused on calculating the flow rates of working fluids and coolants and thermodynamic parameters at all points of the flowcharts, as well as the structural characteristics of the plant elements. The problems of optimizing the parameters of these plants related to the problems of nonlinear mathematical programming are formulated. As an efficiency criterion, the price of electricity is used at given value of the internal rate of return on investment. Optimization calculations were carried out with a carbon tax in the range from $0 \$ / t$ to $140 \$ / t$ in increments of $20 \$ / t$. It is shown that with an increase in the charge for emissions, the optimal efficiency of the plants increases, as well as the specific investment. Specific $\mathrm{CO}_{2}$ emissions are reduced. Throughout the entire range of carbon tax values, IGCC power plant has the best economic and environmental indicators.
\end{abstract}

Keywords - Carbon tax; $\mathrm{CO}_{2}$ emission; optimization parameters of power plants

\section{INTRODUCTION}

About $40 \%$ of the world's $\mathrm{CO}_{2}$ emissions are generated by fossil fuel-fired power plants, with $75 \%$ of this coming from coal-fired power plants [1].

Despite the rapid development of renewable energy in a number of countries, continue the construction of a solid fuel burning power plant (China, India, etc.). In this regard, the problem of reducing $\mathrm{CO}_{2}$ emissions by newly commissioned coal-fired power plants remains urgent, due to the negative impact of rising atmospheric $\mathrm{CO}_{2}$ concentrations on the planet's climate [2].

One of the most effective tools to reduce $\mathrm{CO}_{2}$ emissions is to tax for these emissions [3].

A significant number of studies have been carried out evaluating how the tax value of the $\mathrm{CO}_{2}$ emissions (carbon tax) affects the cost of electricity. Moreover, such studies are carried out both for power plants not equipped with the post-combustion $\mathrm{CO}_{2}$ capture (PCC) systems, for example [4], [5], and equipped with such systems, for example [6]-[8]. It should be noted that these studies were carried out, as a rule, at fixed values of the parameters of the

\footnotetext{
* Corresponding author.

E-mail address: isem777@mail.ru

C2020 Alexander Kler, Pavel Zharkov, Yulia Potanina, Andrey Marinchenko, Nikolai Epishkin. This is an open access article licensed under the Creative Commons Attribution License (http://creativecommons.org/ licenses/by/4.0), in the manner agreed with Sciendo.
} 
thermodynamic cycle of the power plants [9]. First of all, the results of such studies make it possible to assess the change in the competitiveness of various power units. At the same time, the effect of the carbon tax value on the optimal technical parameters of the power plants was not considered. At the same time, with the growth of this board, it becomes advisable to change the parameters so that the energy efficiency of the power plant increases, and the specific $\mathrm{CO}_{2}$ emissions (per unit of electricity) decrease (even due to a very significant increase in specific (per unit of useful power) investments).

In this paper, we study the change in the optimal parameters, energy and economic indicators of two types of power plants that are prospective for using coal (steam turbine power plant (STP) and integrated gasification combined cycle plant (IGCC)) with a change in the carbon tax value.

\section{Methods ANd Methodology}

\section{Research Problem Statement}

The research is based on the optimization calculations of these power plants according to the criterion of the minimum cost of electricity at a given level of internal rate of return on investments. For optimization, an effective gradient method of nonlinear mathematical programming is used [10]. In this case, sufficiently detailed mathematical models of these power plants are used. In these mathematical models, the design calculation of the elements of the technological schemes installations is carried out (heat exchangers of various types, elements of turbomachines, combustion chambers, gasifiers, etc.).

On the basis of the design characteristics of the elements determined as a result of the calculation, the investments in these elements and the plant, the generated electric power, the energy consumption for own needs, etc. are determined.

Optimization is carried out according to a large number of thermodynamic cycle parameters (pressure and enthalpy of live and reheat steam, etc. for STP; pressure and temperature of coal gasification process, blast air flow, etc. for IGCC), as well as design parameters of some elements (steps and diameters of pipes of heat exchangers, etc.). More than a hundred parameters are optimized for each of these power plants. A significant number of inequality constraints are allowed that determine the physically and technically permissible range of elements parameters (constraints on the temperature of combustion and gasification processes, constraints on the ultimate mechanical stresses of the pipes metal, the maximum humidity of the steam leaving the low-pressure part of the turbine, etc.).

Assuming a uniform distribution of capital investments over the years of construction and the same values of the useful annual electricity output, fuel rate and annual semi-fixed operating costs, the cost of electricity is determined from the expression:

$$
C O E=\left(T C I \cdot A+F C+A S F O C+A D+U_{\mathrm{CO}_{2}}\right) / E_{\text {year }},
$$

where 


$$
A=\frac{\sum_{t=1}^{C o P}\left(\frac{1}{1+C R F}\right)^{t-1}}{C o P \cdot \sum_{t=C o P+1}^{C o P+Q p P}\left(\frac{1}{1+C R F}\right)^{t-1}},
$$

$U_{\mathrm{CO}_{2}}=G_{\mathrm{CO}_{2}}^{\text {vear }} \cdot C_{\mathrm{CO}_{2}} \quad$ annual $\mathrm{CO}_{2}$ emissions cost;

$F C=3.6 m_{\text {coal }} \cdot c_{\text {coal }} \cdot N$ annual fuel costs;

$A S F O C=T C I \cdot \alpha_{A S F O C}$ annual semi-fixed operating costs;

$A D=T C I \cdot \alpha_{A D} \quad$ annual depreciation charges;

$G_{\mathrm{CO}_{2}}^{\text {year }} \quad$ annual $\mathrm{CO}_{2}$ emissions;

$C_{\mathrm{CO}_{2}} \quad$ carbon tax;

$\mathrm{CoP} \quad$ construction period;

$O p P \quad$ operation period;

$C R F \quad$ capital recovery factor;

TCI total capital investment;

$E_{\text {year }} \quad$ useful annual electricity output;

$m_{\text {coal }} \quad$ coal mass flow rate;

$c_{\text {coal }} \quad$ coal price;

$N \quad$ the number of plant operation hours each year;

$\alpha_{A S F O C} \quad$ shares of annual costs on semi-fixed operating costs;

$\alpha_{A D} \quad$ depreciation charges.

Optimization was carried out at various $C_{\mathrm{CO}_{2}}$ values, including at zero value.

The carbon capture and utilization (CCU) and the carbon capture and storage (CCS) technologies does not study in this paper. The reducing of $\mathrm{CO}_{2}$ emissions is achieved only through increasing energy efficiency.

\section{Mathematical Models of the Researched Power Plants}

Fig. 1 presents the flow diagram of the steam power plant.

The mathematical model of STP includes 1050 set parameters, 1294 calculated parameters, and, for 34 parameters it was necessary to set the initial approximation. A detailed description this plant scheme and models of its elements are given in [10].

The schematic diagram of IGCC is shown in Fig. 2. 


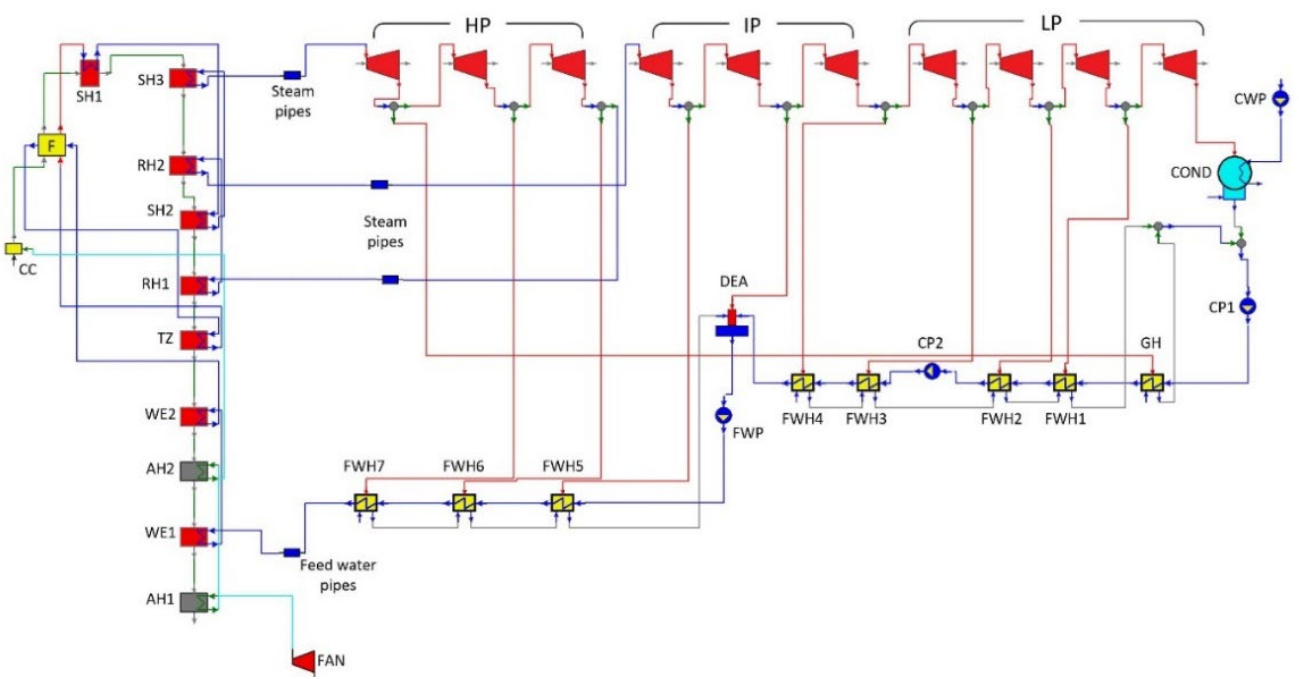

Fig. 1. The schematic diagram of steam turbine power plant. FAN - air fan; SG - steam generator; CC - combustion chamber; F - furnace; SH1-SH3 - superheaters; RH1, RH2 - reheaters; TZ - zone of maximum heat capacity; WE1, WE2 - water economizers; AH1, AH2 - air heaters; HP - high-pressure turbine; IP - intermediate pressure turbine; LP low-pressure turbine; GEN - electric generator; COND - condenser; CWP - circle water pump; CP1, CP2 - condensed water pumps; GH - gland heater; FWH1-FWH4 - low-pressure feed water heaters; DEA - deaerator; FWH5-FWH7 high-pressure feed water heaters.

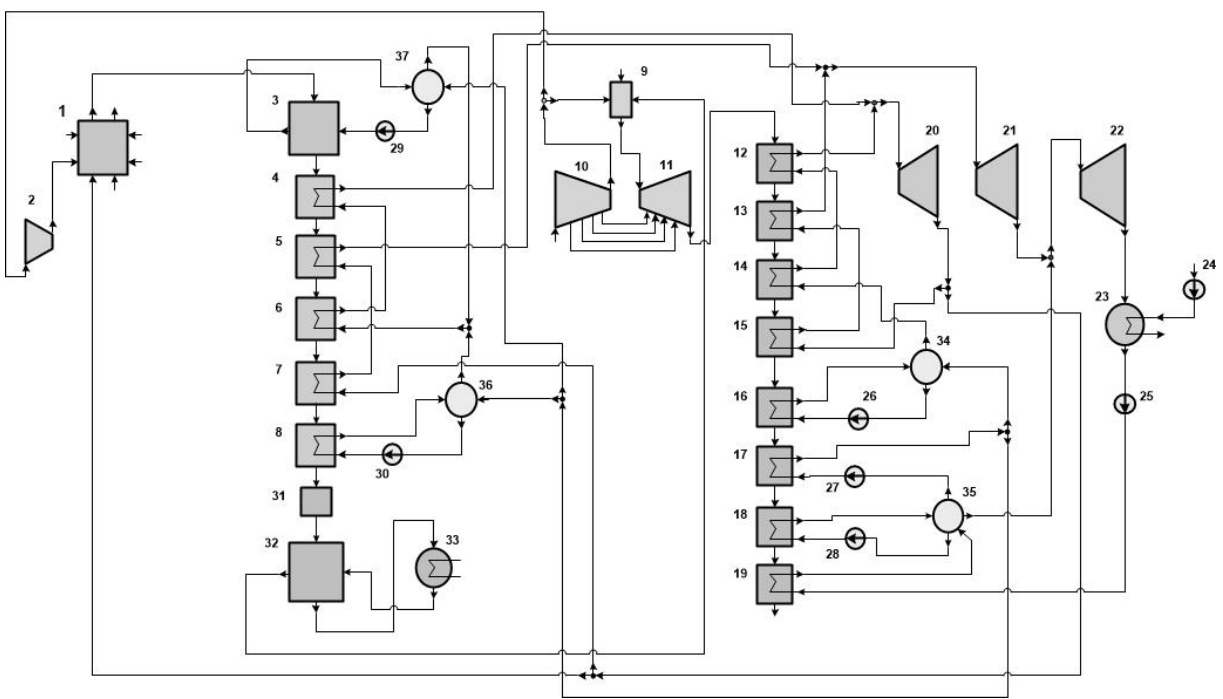

Fig. 2. The schematic diagram of integrated gasification combined cycle plant. 1 - gasifier; 2 - air compressor 1 ; 3 - furnace of gas generator; 4-8 - waste-heat boiler on gasification products; 9 - combustion chamber of gas turbine; 10 - air compressor; 11 - gas turbine; 12-19 - waste-heat boiler on combustion products; 20-22 - compartments of steam turbine; 23 - condenser; 24 - circulation pump of process water supply system; 25 - condensate pump; 26 - circulation pump of high pressure loop of boiler on combustion products; 27 - feed water pump; 28 - circulation pump of low pressure loop of boiler on combustion products; 29 - circulation pump of high-pressure loop of boiler on gasification products; 30 - circulation pump of low-pressure loop of boiler on gasification products; 31-33 - ash and sulphur removal; 34-37 drum separators. 
$2020 / 24$

The mathematical model of IGCC includes 1026 set parameters, 963 calculated parameters, and, for 17 parameters it was necessary to set the initial approximation. A detailed description this plant scheme and models of its elements are given in [11].

\section{The initial techno-economic information}

In the optimization calculations it was accepted: the number of plant operation hours each year -7000 hours; construction period -4 years; operation period -30 years; internal rate of return on investment -0.15 ; coal price $-100 \$ /$ tce, shares of annual costs on semi-fixed operating costs -0.04 ; depreciation charges -0.03 .

During optimization, the carbon tax value varied from $0 \$ / \mathrm{t}$ to $140 \$ / \mathrm{t}$ in increments of 20. For each power plant, 8 calculations were performed.

\section{Results}

The results of the optimization calculations are presented in Table 1 for STP, and in Table 2 for IGCC. The results contain the optimal values of the economic and energy indicators and some thermodynamic cycle parameters, depending on the carbon tax value.

TABle 1. Main Results of the Optimization CALCUlations of SteAm TURBINE Unit

\begin{tabular}{|c|c|c|c|c|c|c|c|c|}
\hline \multirow[t]{2}{*}{ Parameters } & \multicolumn{8}{|c|}{ Carbon TAX, $\$ / \mathbf{t}$} \\
\hline & $\mathbf{0}$ & 20 & 40 & 60 & 80 & 100 & 120 & 140 \\
\hline Cost of electricity, \$/MWh & 99.6 & 117.2 & 134.0 & 150.6 & 167.6 & 184.1 & 201.2 & 217.4 \\
\hline $\begin{array}{l}\text { Specific plant investment in } \\
\text { the installed capacity, } \$ / \mathrm{kW}\end{array}$ & 1908 & 1912 & 1919 & 1926 & 1951 & 1969 & 1987 & 2003 \\
\hline Net efficiency, \% & 42.87 & 43.2 & 43.61 & 44.01 & 44.47 & 44.69 & 44.81 & 44.91 \\
\hline $\begin{array}{l}\text { Specific } \mathrm{CO}_{2} \text { emissions, } \\
\mathrm{kg} / \mathrm{MWh}\end{array}$ & 867.3 & 858.8 & 851.1 & 842.9 & 835.2 & 831.1 & 829.2 & 828.4 \\
\hline Live steam pressure, MPa & 19.21 & 19.79 & 20.14 & 20.66 & 21.42 & 21.79 & 22.25 & 22.43 \\
\hline Live steam temperature, ${ }^{\circ} \mathrm{C}$ & 618.5 & 622 & 630.1 & 632.7 & 636.5 & 635.2 & 633.7 & 632.8 \\
\hline Reheat steam pressure, MPa & 4.24 & 4.35 & 4.42 & 4.55 & 4.66 & 4.75 & 5.03 & 5.18 \\
\hline Reheat steam pressure, ${ }^{\circ} \mathrm{C}$ & 542.2 & 545.2 & 555.8 & 569.6 & 585.6 & 589.4 & 592.4 & 596.9 \\
\hline
\end{tabular}

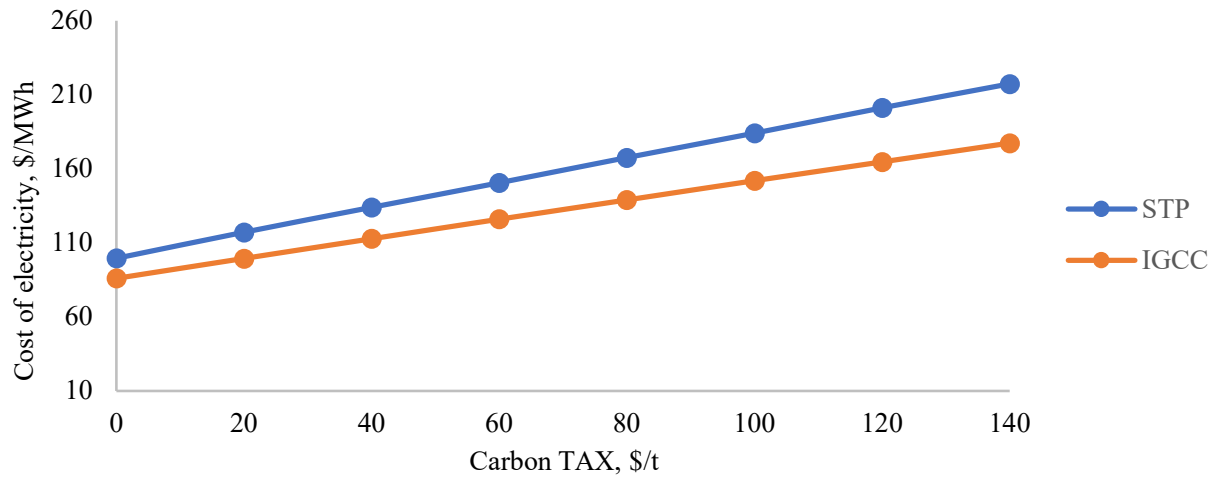

Fig. 3. Cost of electricity versus carbon tax. 


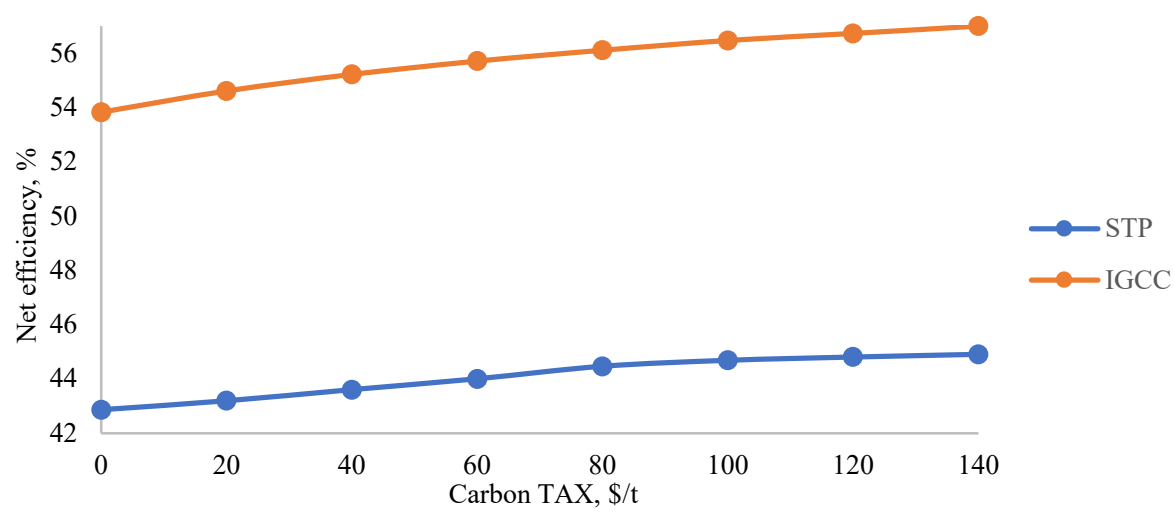

Fig. 4. Net efficiency versus carbon tax.

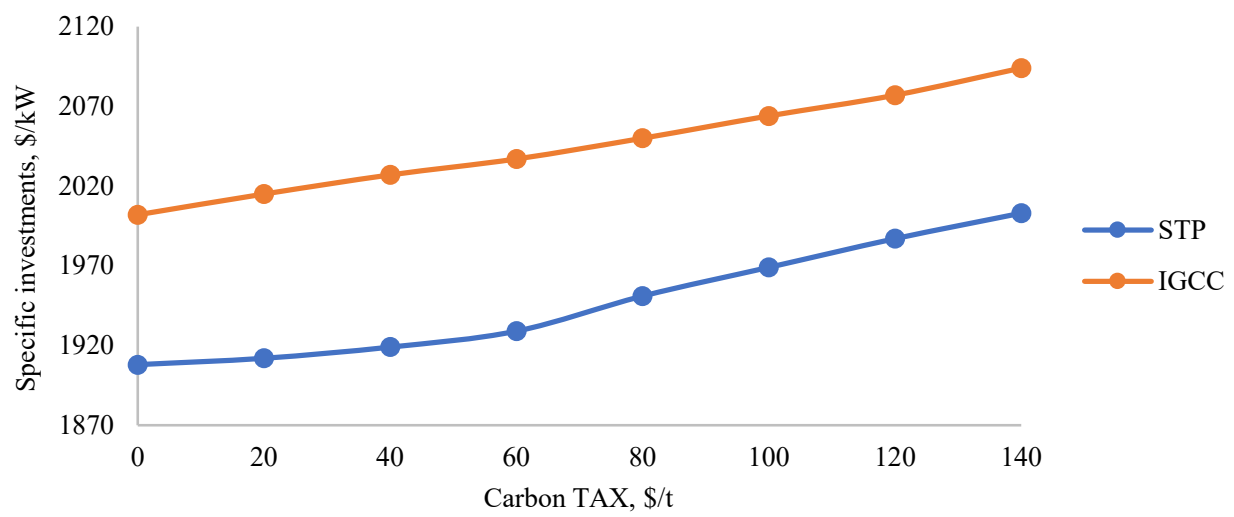

Fig. 5. The lowest specific investments versus carbon tax.

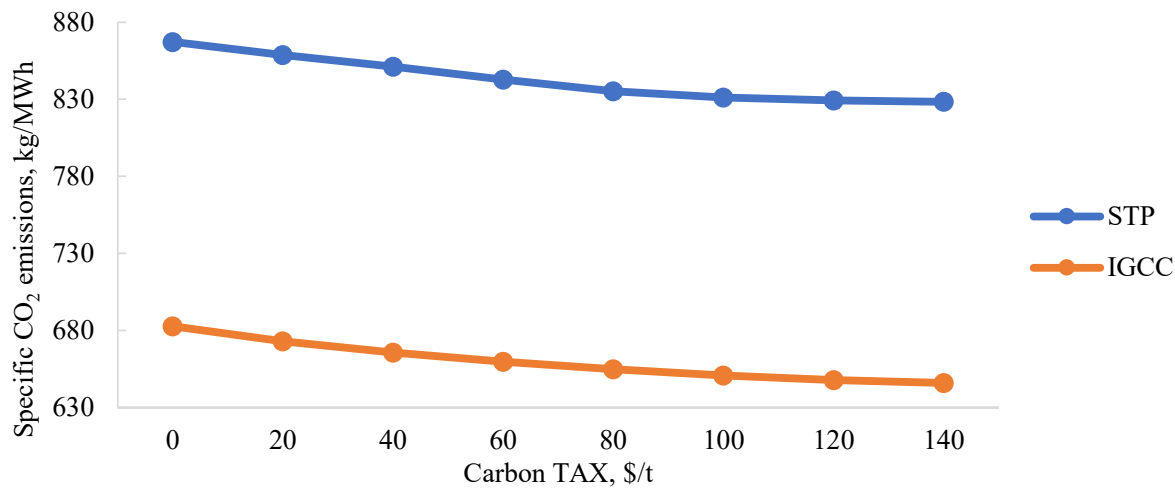

Fig. 6. The specific $\mathrm{CO}_{2}$ emission versus carbon tax. 
Fig. 3-6 show the change in the most important indicators of the two power plants under study, depending on carbon tax value.

TABle 2. MAIN RESUltS OF THE OPTIMIZATION CALCULATIONS OF INTEGRATED GASIFICATION COMBINED CYCLE PLANT

\begin{tabular}{|c|c|c|c|c|c|c|c|c|}
\hline \multirow[t]{2}{*}{ Parameters } & \multicolumn{8}{|c|}{ Carbon TAX, \$/t } \\
\hline & $\mathbf{0}$ & 20 & 40 & 60 & 80 & 100 & 120 & 140 \\
\hline $\begin{array}{l}\text { Cost of electricity, } \\
\$ / \mathbf{M W h}\end{array}$ & 86.2 & 99.5 & 112.7 & 126.1 & 139.3 & 152.1 & 164.7 & 177.0 \\
\hline $\begin{array}{l}\text { Specific plant } \\
\text { investment to the } \\
\text { installed capacity, } \\
\$ / \mathbf{k W}\end{array}$ & 2002 & 2015 & 2027 & 2037 & 2050 & 2064 & 2077 & 2094 \\
\hline Net efficiency, $\%$ & 53.83 & 54.61 & 55.22 & 55.71 & 56.11 & 56.47 & 56.73 & 57 \\
\hline $\begin{array}{l}\text { Useful capacity, } \\
\text { MW }\end{array}$ & 434.7 & 441.0 & 445.6 & 449.9 & 453.2 & 456.0 & 458.2 & 460.5 \\
\hline $\begin{array}{l}\text { Specific } \mathrm{CO}_{2} \\
\text { emissions, } \mathrm{kg} / \mathrm{MWh}\end{array}$ & 682.7 & 673.0 & 665.6 & 659.7 & 654.9 & 650.9 & 647.8 & 644.1 \\
\hline $\begin{array}{l}\text { Live steam } \\
\text { pressure, MPa }\end{array}$ & 15.2 & 15.2 & 15.2 & 15.2 & 15.2 & 15.2 & 15.2 & 15.2 \\
\hline $\begin{array}{l}\text { Live steam } \\
\text { temperature, }{ }^{\circ} \mathrm{C}\end{array}$ & 522 & 525 & 530 & 531 & 535 & 535 & 536 & 538 \\
\hline $\begin{array}{l}\text { Reheat steam } \\
\text { pressure, MPa }\end{array}$ & 1.13 & 1.22 & 1.29 & 1.35 & 1.43 & 1.49 & 1.52 & 1.59 \\
\hline $\begin{array}{l}\text { Reheat steam } \\
\text { pressure, }{ }^{\circ} \mathbf{C}\end{array}$ & 487 & 489 & 490 & 490 & 491 & 491 & 492 & 493 \\
\hline
\end{tabular}

\section{DISCUSSION}

As can be seen from the presented results of optimization research, with an increase in the carbon tax, the optimal net energy efficiency values for both plants increase, which leads to reduction $\mathrm{CO}_{2}$ emissions per unit of electricity output. At the same time, the specific investment in both plants is increasing. For STP the transition of carbon tax value from $0 \$ / t$ to $70 \$ / t$ gives a much greater effect the growth of net energy efficiency $(1.37 \%)$ than the transition from $70 \$ / t$ to $140 \$ / t(0.67 \%)$. Moreover, the first value of the increase in net energy efficiency is provided due to a much smaller increase specific investments $(32 \$ / \mathrm{kW})$ than the second value of the increase $(63 \$ / \mathrm{kW})$.

Similar phenomena are observed for IGCC.

In the considered range of carbon tax value, specific $\mathrm{CO}_{2}$ emissions are reduced for STP from $867.3 \mathrm{~kg} / \mathrm{MWh}$ to $828.4 \mathrm{~kg} / \mathrm{MWh}$ and for IGCC from $682.7 \mathrm{~kg} / \mathrm{MWh}$ to $644.1 \mathrm{~kg} / \mathrm{MWh}$. The dependence of the cost of electricity on the carbon tax for both plants is close to linear, and for STP there is a greater increase than for the IGCC. 


\section{CONCLUSION}

- Mathematical models of two promising coal power plants have been developed: a steam turbine power plant with coal dust burning in a steam boiler and integrated gasification combined cycle plant;

- Optimization studies of two promising coal plants were carried out according to the criterion of the minimum cost of electricity for a given rate of return on investment;

- Researches have shown that with an increase in carbon tax, the optimum value of net energy efficiency increases; the specific $\mathrm{CO}_{2}$ emissions for both plants are reduced. At the same time, the costs of electricity are almost linearly rising;

- For both plants, the same change of the carbon tax value, with a small initial value, gives a significantly greater increase of energy efficiency than with a larger initial value. Moreover, the first increase in energy efficiency is provided due to a much smaller increase in specific investment than the second increase in energy efficiency;

- Throughout the studied range of carbon tax values IGCC gives a lower cost of electricity than STP, which is associated with a higher energy efficiency of IGCC. This suggests that justified efforts to create serial samples of these power plants.

\section{ACKNOWLEDGEMENT}

The work was carried out under State Assignment, Project 17.1.1(reg. number AAAA-A17-117030310433-6) of Fundamental Research of Siberian Branch of the Russian Academy of Sciences.

\section{REFERENCES}

[1] Kanniche M., Moullec Y. L., Authier O., Hagi H., Bontemps D., Neveux T., Louis-Louisy M. Up-to-date CO $\mathrm{CO}_{2}$ capture in thermal power plants. Energy Procedia 2017:114:95-103. https://doi.org/10.1016/j.egypro.2017.03.1152

[2] Gravelsins A., Bazbauers G., Blumberga A., Blumberga D. Power Sector Flexibility through Power-to-Heat and Power-to-Gas Application - System Dynamics Approach. Environmental and Climate Technologies 2019:23(3):319-332. https://doi.org/10.2478/rtuect-2019-0098

[3] Blumberga D., Chen B., Ozarska A., Indzere Z., Lauka D. Energy, Bioeconomy, Climate Changes and Environment Nexus. Environmental and Climate Technologies 2019:23(3):370-392. https://doi.org/10.2478/rtuect-2019-0102

[4] Locatelli G., Mancini M. Small-medium sized nuclear coal and gas power plant: A probabilistic analysis of their financial performances and influence of $\mathrm{CO}_{2}$ cost. Energy Policy 2010:38(10):6360-6374.

https://doi.org/10.1016/i.enpol.2010.06.027

[5] Supekar S. D., Skerlos S. J. Reassessing the Efficiency Penalty from Carbon Capture in Coal-Fired Power Plants. Environmental Science \& Technology 2015:49(20):12576-12584. https://doi.org/10.1021/acs.est.5b03052

[6] Siefert N. S., Litster S. Exergy and economic analyses of advanced IGCC-CCS and IGFC-CCS power plants. Applied Energy 2013:107:315-328. https://doi.org/10.1016/j.apenergy.2013.02.006

[7] Bohm M. C., Herzog H. J., Parsons J. E., Sekar R. C. Capture-ready coal plants - Options, technologies and economics. International J. Greenhouse Gas Control 2007:1(1):113-120. https://doi.org/10.1016/S1750-5836(07)00033-3

[8] Pettinau A., Ferrara F., Tola V., Cau G. Techno-economic comparison between different technologies for $\mathrm{CO}_{2}$-free power generation from coal. Applied Energy 2017:193:426-439. https://doi.org/10.1016/j.apenergy.2017.02.056

[9] Meneses L. R., Silva J. C., Cota S., Kikas T. Thermodynamic, Environmental and Economic Simulation of an Organic Rankine Cycle (ORC) for Waste Heat Recovery: Terceira Island Case Study. Environmental and Climate Technologies 2019:23(2):347-365. https://doi.org/10.2478/rtuect-2019-0073

[10] Kler A. M., Zharkov P. V., Epishkin N. O. Parametric optimization of supercritical power plants using gradient methods. Energy 2019:189:116230. https://doi.org/10.1016/j.energy.2019.116230

[11] Kler A. M., Potanina Y. M., Marinchenko A. Y. Co-optimization of thermal power plant flowchart, thermodynamic cycle parameters, and design parameters of components. Energy 2020:193:116679. https://doi.org/10.1016/j.energy.2019.116679 